\title{
"FLIPPED CLASSROOM" AS A NEW METHOD OF TEACHING ENGLISH IN HIGHER EDUCATION
}

\begin{abstract}
Summary. The article discusses relevant issues of using flipped learning technology in teaching foreign languages at universities. Flipped learning with help of network interaction using computer and the Internet can be successful if the role of students and their autonomy is strengthened in the learning process, and the emphasis is shifted from teaching to learning, from lecturer to student.

As a result of the research, the "flipped classroom" method has established itself as an effective, innovative, and accessible technology for both the teacher and the student, among foreign and Ukrainian teachers. This technology is very perspective, which proves the close attention of researchers and scientists around the world (A. Sams, J. Bergman, E. Mazur, etc.).

This technology is being actively used by many teachers in the educational process both abroad and in Ukraine, which proves its universality and applicability to any conditions and requirements. At the moment, in Ukraine, the use of this technology is not yet widespread as in other countries, but there are already developments and research in this innovative area. A significant advantage of using the "flipped classroom" technology is practical orientation, that is, in-class learning time is spent on self-directed work and on interacting with other students. The self-directed learning experience contributes to the intensive development of the student's personal qualities, critical thinking, as well as achieving substantive results. The perspective of this research is in the exchange of experience in special forums, where teachers from all over the world evaluate and give constructive criticism to the developed lesson or research results, because the exchange of experience and knowledge expands the possibilities of using the technology, improving it every time.
\end{abstract}

Key words: flipped classroom, flipped teaching, lecturer, student, higher education, creativity, critical thinking.

Introduction. To improve the quality of education, it is necessary to introduce new approaches to learning that are more adapted to the needs of modern students. In the context of constant economic and social changes, it is very important to teach students to learn independently, constantly improve their skills and update their knowledge throughout life. In this regard, the teacher faces the difficult task of choosing the forms and methods of organizing educational activities, the implementation of which in the specific conditions of the institution of higher education will give a high level of quality training of students.

Recently, blended learning is widespread abroad, which consists in the active use of elements of distance learning, learning platforms, electronic educational resources, digital technologies and the Internet. One of the latest trends in foreign pedagogy of developed countries is the technology "Flipped classroom", which is a form of blended learning [1, p. 138]. It is a new approach to the organization of learning, in which in-class learning is interchanged with distance learning.

The purpose of this article is to analyze the innovative methodology "Flipped classroom" to form motivation and improve the quality of knowledge among students.

Materials and methods. The "Flipped classroom" learning model is getting more relevant and innovative in modern education. The researchers use this methodology in the process of teaching a foreign language to increase students' motivation (N. Halskova, B. Mandel, E. Mazur, J. Bergmann, A. Sams, C. Bonk, etc.). This method has more flexibility and provides better encouragement of students to the learning process, allowing you to create a dynamic and creative environment in which students learn to think critically and work together on tasks.

Main body. A distinctive feature of the flipped classroom is the complete or partial transfer of the tasks to self-directed learning. At the same time, in-class learning time is used for interactive activities that develop critical thinking and creativity. M. Lebrun is one of the authors of the book "Flipped Learning", writes that flipped teaching is not essentially a new method, but rather represents a new way of thinking, the purpose of which is to optimize in-class learning with students through distance learning. It aimed at the in-depth study of the subject [2, p. 15]. The teacher's task is to motivate students to improve their knowledge outside the in-class learning time, to teach not only to search for information, but also to check its reliability, analyze, critically reflect, and then to achieve an active intellectual reaction to the educational material in the classroom, which is a mandatory condition for mastering new knowledge.

The term "Flipped classroom" is used relatively recently, some of its principles have been used by teachers for a long time. E. Mazur, a physics lecturer at Harvard University in the USA, gave the students material of lectures in advance. They have come to the lessons prepared and with knowledge of new concepts and terminology. At the beginning of the lesson, E. Mazur conducted a small survey, the results of which were a signal for the lecturer, how much the teaching material was mastered, what issues should be paid special attention to. Unlike traditional physics lectures, E. Mazur did not show how to solve similar problems, encouraging students to think about and apply general principles and theories in different situations. Final tests conducted by E. Mazur demonstrated a higher level of mastering the educational material in comparison with the traditional teaching method [3, p. 67].

The term "Flipped classroom" was first used in 2007, when two high school chemistry teachers in the United States, D. Bergman, and A. Sams, began to distribute video lessons instead of printed materials to their students. Video lessons could be used to study new educational material at home. The school where D. Bergman and A. Sams 
worked was in the countryside; students often missed classes. To save their time and have no additional lessons with the absent, the teachers came up with the idea to record their lessons on video. Students who missed the lesson could watch the video of this lesson at home at a convenient time for them. The students enthusiastically embraced the proposed approach to self-directed learning the material. Moreover, those who attended the class began to watch the video lessons, especially during the preparation for the exams. According to D. Bergman and A. Sams, as a result of the experiment, the number of underperforming students significantly decreased [4, p. 37]. The success of the video tutorials served as an impulse for further development and experimental testing of this idea.

This method became a small «revolution» concerning traditional education and the possibility of professional development and self-improvement for progressive teachers. They focused their efforts on student-centered learning and the development of students' competencies. There are several forms of flipped learning $[5$, p. 52]. The classical model of flipped learning assumes the previous familiarization of the student with the theoretical material of the next lesson. Preparation materials can be given in the form of lectures or a paragraph of the textbook, presentations, video, and audio records. The teacher organizes a discussion of the studied material in the classroom, explains difficult moments, answers questions, uses interactive teaching methods. It should be noted that although training is partially carried out remotely, this model continues to resemble the traditional education system: first, theories, concepts, and models are studied, and then their practical application. The following model of flipped learning, conditionally called "advanced", also provides for two stages - in-class learning and distance learning and implies a gradual complication of the level of tasks and expansion of activities [6, p. 4].

During the previous training, students independently search for information, read articles, watch videos, in mini-groups, or individually prepared theses that they will be present in the audience, questions for debate, or round table. The results of work they post on a study platform so that the teacher and other students can have the opportunity to familiarize themselves in advance and better prepare for the lesson.

Thus, the self-directed work of each student is monitored. In the classroom, a discussion of reading material, argued analysis of the work of each group, creating a common conceptual picture based on opinions, comments made by judgments, or a mini-colloquium, in which one group makes a presentation, and the other organizes debates. The system or combined model of a flipped classroom involves the combination of the first two models. The essence of this model is to change not the place of execution of a certain type of activity, but in the permutation of key components of the educational process. The traditional sequence of involved competencies is changing (memorization, understanding, application, analysis, synthesis, assessment). First, the practical application of the theory or model is being studied and only then its theoretical substantiation. This model of flipped learning is the pedagogical approach, the most close to reality.

At the remote stage, students in mini-groups work with a task or a problematic situation, trying to evaluate it, search and analyze the information necessary for an objective evaluation of events, offer solutions. Students represent the information and sources, under the guidance of the teacher, analyze the task, compare the advantages and disadvantages of each of the proposed solutions.
After that, the remote stage should be again, during which students study theoretical foundations of the issue, experience in the indicated problem. At the final stage, the outcomes of the total material of the topic are summed up. The applicability of this model or theory for other situations is analyzed [7, p. 21].

This approach changes the nature of knowledge. Knowledge is logically structured in the traditional pedagogy. Flipped learning requires the active participation of the student in the study process. The role of the teacher is also changing. The teacher becomes a tutor, organizer of various types of student activities, accompanying in the formation of certain competencies [8, p. 97].

Flipped classroom technology significantly changes the process of traditional assessment based on the reproduction of knowledge and its application in a clearly defined academic situation. Various models of a flipped classroom allow you to use a wider number of forms of students' knowledge control, depending on the tasks. In case the information was not reported by the teacher, and the students had to find it, the used approaches to search for information are evaluated, as well as the quality of the information itself. One of the important features of flipped learning is interdisciplinary. In a traditional university, problem situations are highly theoretical, since most often they are developed within the same discipline. However, graduates will face real problems in future professional practice, which often require an interdisciplinary approach, and the complexity of their solution is caused by their interdisciplinary character. It should be emphasized that flipped learning is not a completely new method, it intersects with various approaches, such as student-centered learning, problem learning, competence-based approach, system-activity approach. J. Bishop, lecturer at the University of Utah (USA) and an active supporter of flipped learning, writes that there is always a small proportion of participants in the experimental group who are rather restrained about the idea of flipped learning or against changes [9, p. 3].

In our opinion, to stimulate the distance learning of students, it is necessary to organize the educational process in such a way that students realize the benefits of their independent work and actively use its results in the educational process. It is advisable to use, according to scientists, active forms of activity, for participation in which preliminary independent preparation is required. This can be the preparation of abstracts for a presentation in the classroom, questions for an interview, a round table, or a debate. In addition, additional work for teachers is a serious obstacle to the use of flipped classroom technology in Ukrainian universities. To prepare high-quality materials for the distance learning of students, the teacher must not only process a significant amount of information, but also arrange everything nicely and efficiently. Often teachers do not have sufficient knowledge in the field of information technology application. If this work is not additionally supported by management, few teachers will agree to drastically change their style of work. This requires technical and administrative support, which is very time consuming and costly. Technical equipment is also a problem. Flipped teaching requires the appropriate technical equipment of all classrooms, as well as the personal information space of the teacher and students, constant access to the Internet, but even in this case, no one is immune from "failures" in the operation of technology. Despite the problems that complicate the implementation of flipped education in universities, this technology, according to foreign and Ukrainian researchers, has a lot of advantages compared with the traditional education system. 
The quality of education is determined by the quality of the teacher's knowledge. "Flipped learning" is an effective method of improving quality by developing lecturers' professional skills, improving working methods, expanding strategies, and introducing new educational technologies. The advantage of the method lies in its flexibility, in the ability of each teacher to use in each specific situation the best option. The use of active forms of work in-class learning time contributes to the development of emotional relationships between all participants in the educational process, creates conditions for strengthening the intellectual and creative component of learning and improving the quality of the educational process [10, p. 203].

The effectively organized distance learning develops independence, initiative, self-discipline, and social responsibility in students. Flipped learning allows you to gradually increase the volume and complexity of tasks, taking into account the level of knowledge of students. It becomes an effective way to achieve a goal. A student, when performing high-quality independent work, receives much more theoretical information and practical skills. At the same time, the student can revise or re-read the teaching materials several times, can work in a rhythm convenient for him, in a comfortable place, can formulate and send a question to the teacher.

The technologies of the flipped classroom in the educational process will complicate the work of teachers, will require mastering new pedagogical techniques, studying the specifics of the specialty of future graduates, preparing new materials, creating multimedia content; but this work will pay off by improving the quality of student training.

Conclusions. Modern higher education is being transformed by integrating into the digital space. It means that teachers need to keep up with the times, developing and implementing modern information technologies. As the experience of Ukrainian and foreign educational institutions shows, flipped classroom technology is actively used in the educational process using various online platforms. The innovativeness and originality of the authors' work lie in the adaptation of the methodology in high education. In the context of virtualization of life and public communications, it is necessary to use new approaches to learning, more adapted to the needs of today's students, and changes in the role of the teachers.

\section{References:}

1. Bonk C., Graham Ch. The Handbook of Blended Learning: Global Perspectives, Local Designs. San Francisco, 2006. 624 p.

2. Захарова А. Опыт организации образовательной деятельности в условиях перехода вуза к оригинальным образовательным стандартам. Высшее образование сегодня. Москва : ООО «Издательская группа «Логос», 2012. № 9. С. 14-20.

3. Mazur E. Peer instruction: a user's manual. Prentice-Hall : Upper Saddle River, 1997. 252 p.

4. Bergmann J., Sams A. Flip your classroom: reach every student in every class every day. Washington, DC : International Society for Technology in Education, 2012. $122 \mathrm{p}$.

5. Гальскова Н. Современная методика обучения иностранным языкам : пособие для учителя. 2-е изд. Москва : АРКТИ, 2003. $192 \mathrm{c}$.

6. Соловьев В., Перескокова Т. Организация учебного процесса для повышения качества образования. Высшее образование сегодня. 2014. № 10. C. 2-6.
7. Christensen C., Horn M., Staker H. Is K-12 Blended Learning Disruptive? An Introduction of the Theory of Hybrids. Lexington, MA: The Clayton Christensen Institute, 2013. 48 p. URL: https://files. eric.ed.gov/fulltext/ED566878.pdf.

8. Мандель Б. Современные и традиционные технологии педагогического мастерства : учебное пособие для магистрантов. Москва : Директ-Медиа, 2015. 260 с.

9. Bishop J., Verleger M. The flipped classroom: a survey of the research. 2013 ASEE Annual Conference \& Exposition, June 23-26, 2013. Atlanta, 2013. P. 1-18. URL: https://www.researchgate.net/ publication/285935974_The_flipped_classroom_A_survey_of_the research.

10. Айнутдинова И. Инновационные технологии в обучении иностранным языкам в вузе: интеграция профессиональной и иноязычной подготовки конкурентоспособного специалиста (зарубежный и российский опыт) : настольная книга педагога-новатора. Казань, 2011. 456 c. URL: https://kpfu.ru/staff_files/F_1661228521/03 Ainoutdinova_Innov_techs_monograph_2011.pdf.

Шерстюк Н. «Перевернутий клас» як новий метод викладання англійської мови в закладах вищої освіти

Анотація. У статті розглядається застосування методики перевернутого навчання (flipped learning) під час вивчення іноземних мов у закладах вищої освіти. Перевернуте навчання тісно взаємодіє з використанням комп'ютера та інтернету. Ця педагогічна модель може бути успішною, якщо у процесі навчання буде посилена роль студентів та їхньої автономії, а акценти будуть перенесені з викладання на навчання, з викладача на студента.

В умовах віртуалізації життєдіяльності та громадських комунікацій необхідно запроваджувати нові підходи до навчання, що будуть більш пристосованими до потреб сучасних студентів. Останнім часом у навчальних закладах розвинених країн поширення набула технологія «перевернутий клас», яка $є$ однією з форм змішаного навчання.

У результаті проведеного дослідження з'ясовано, що технологія «перевернутий клас» («flipped classroom») зарекомендувала себе як ефективна, інноваційна й доступна як для викладача, так і для студента. Ця методика активно впроваджується в навчальний процес багатьма зарубіжними та українськими викладачами, що доводить іï універсальність і застосовність до будьяких умов та вимог. На цей час в Україні застосування зазначеної технології не настільки поширене, як в інших країнах, проте вже $є$ певні напрацювання та дослідження в цій інноваційній сфері. Значною перевагою використання технологіï «flipped classroom» $€$ практико-орієнтованість, тобто більша кількість аудиторного часу приділяється відпрацюванню, взаємодії з іншими студентами 3 метою передачі досвіду самостійного навчання, що сприяє інтенсивному розвитку особистісних якостей студента, його автономності, критичного мислення, а також досягненню предметних результатів. Перспектива дослідження полягає в обміні досвідом на спеціальних форумах, де педагоги 3 усього світу оцінюють і піддають конструктивній критиці розроблені заняття чи результати досліджень, адже обмін досвідом і знаннями розширює можливості 3 покращення використання зазначеної технології.

Ключові слова: перевернутий клас, перевернуте навчання, викладач, студент, вища освіта, креативність, критичне мислення. 